\title{
Indigenous Elders' Perspective and Position
}

\section{Harald Gaski}

UiT The Arctic University of Norway

Inspired by a great deal of work on Indigenous methodologies, I feel it natural to start this essay by positioning myself. I will ponder the more or less institutionalized concept of an 'Indigenous Elders' approach.' I will do this from a combined perspective of a Sámi Elder (at least one who is approaching the age of becoming an Elder) and from an academic vantage point in which Indigenous scholarship has been a key instrument in my university practice over the last three-four decades. Although age is not the only qualifying criterion for achieving the status of an Elder, in my case I feel that the experiences that come along with age and growing up in a traditional Sámi community, in addition to the role of a long-time instructor of Sami students in the academy, of being a devoted researcher in the field of transIndigenous studies, and a commentator of cultural and societal development within the Sámi communities, all together should sum up to a position where it is appropriate to say a few words about an issue that has been essential in Indigenous scholarship as the Elders' position.

First, I will comment on the concept itself and its actual status today, and then consider its implications for research. Because storytelling is central to an Elders' approach, although this is an academic essay, it will operate substantially in the manner of a storyteller, leaving, as tradition would dictate, the final interpretation of it to the reader. This approach will also have some consequences for my citation practice in this essay, as it is the whole wide field of Indigenous studies over the last forty years that has inspired me to sit down and try to write something on a matter so much mentioned, but still hardly ever being theorized over. Therefore, I have a list of references at the end of this essay where I mention some of the texts that have inspired me over the years, without actually having any direct quotations or references to them in this essay. The text is meant to be congenial to the common reasoning behind the Elders' roles and position in indigenous communities. It is also a twofold attempt of combining academic writing with storytelling, where the story should be free to flow on its own terms. I think this combination should be practiced more as an attempt to bridge two different kinds of knowledge systems and to disseminate collected wisdom in both indigenous communities and in the academic world. As should be clear to the reader already, this is an overwhelming enterprise for a brief essay, but I feel it is about time that Indigenous scholarship ask the question whether the contended importance of the Elder's position is more rhetorical and ideological than practical and factual today. On a more humoristic note, I may add that I am not doing this just because of my own coming to Elders' age, but more as a challenge to myself to try to tell - in a story format - about the Indigenous Elders' position in an otherwise academically fashioned essay.

The Elder's approach has never been designated as a distinct method within Indigenous research, but in my view there are actually good reasons to put this idea forward - if not as a 
distinct method, then at least as an important source of understanding and way of putting the Indigenous dimension into practice in research. The Elders possess a wealth of knowledge and experience that Indigenous cultures have always valued highly. In a fair amount of methodological discussion, it has been noted that Elders possess competencies that are not necessarily theorized or described in academic language, but that nevertheless are crucial for the cultural knowledge reservoirs. At the same time, we know that traditional cultures have not differentiated between theory and practice, but that theory is embodied within practice that it derives its validation from its functionality; people do what they've always done, because experience proves this way of doing things to be the best working option. Still, it is not a matter of keeping knowledge unchanged, or insisting that the youth value unchanging knowledge, but that the Elders exercise the authority they have within the culture to appraise the traditions and to make sure that changes are implemented with a full cognizance of past ways, a cognizance that can only come from a lifetime of practice.

It is an incontrovertible fact that much Indigenous knowledge both assumes and requires, at a foundational level, that the knowledge possessed and protected by the Elders is a product of a long life based on traditions, values and worldviews they have taken a long time to acquire. Because of this, the Elders' approach can also serve as an example of a well-structured system, one in which experience-based knowledge has its own value, at the same time as it can definitively be used in contemporary Indigenous research, either as an addition, or as an alternative to unnecessarily sharp divides between theory and practice, or between disciplines, for that matter. The Indigenous Elders' knowledge belongs to the realm of traditional knowledge, which is experience-based and often holistic in its approach to Life, Land and Spirituality. It is the burden and business of Indigenous methodologies to develop a trans-Indigenous and cross-cultural framework to make this knowledge applicable for both Indigenous and non-Indigenous scholarship. The ambition should be no less than try to bridge between two different knowledge systems where respect, reciprocity and accountability is required from both sides in order to bring our common world forward.

In Sámi, one can distinguish between diehtu and máhttu, where diehtu represents knowledge that is theory-based (i.e., how one can present and explain a topic), while máhttu stands for the practical application of this knowledge. But even this division is affected by our learned "Western" way of thinking and categorizing, because in everyday speech there is no watertight division between the use of the two terms, especially not as verbs. One can easily say 
Dies in dieđe mun in maidige (I don't know anything about that), without any sort of theoretical puzzlement as the basis for the utterance. One can just as easily say Dien han gal máhtát (You know that already/You can do that easily) as a general comment that something is seen as easy to understand or do, regardless of whether it is connected to theoretical or practical knowledge. In my opinion these are fascinating approaches to explore further in relation to the question of how far traditionally based competence can - or should - be theorized in order to win a place in international discourse on research in Indigenous contexts.

In Sámi contexts there are several terms that can serve as corresponding expressions of what we mean by the Elders' approach. We have the South Sámi expression dåajmijes vuekie (a functional approach to how best to conduct oneself in the local community in order to be a decent person), but this expression is perhaps just as closely connected to what we today would call Indigenous aesthetics - a holistic attitude towards life. We can perhaps say that the North Sámi expression láhttet olbmo láhkái (to behave like a human being) describes something of the same concept, according to ethical and community responsive standards. In the meantime, it is possible to assert that the expression guldalit vuorraset olbmuid (listen to elderly people) best covers what I mean by the Elders' approach. Guldalit is a verb with multiple meanings, of which the most basic are listen to and listen for. The traditional Sámi approach is to listen to, and listen for, messages from Nature, from our fellow creatures, the animals, birds, wind, sky and the Earth. This ability to gullat (hear) has always been respected and regarded as a vital competence for our ongoing survival, not only as Sámi but as human beings in general. It has required affinity and adaptability to our surroundings, and has been transferred through stories and references to specific people and occurrences that have emphasized its importance. This view is also represented in a poem by the renowned, late Sámi multimedia artist, Nils-Aslak Valkeapää, in his book The Earth, My Mother (Sámi original 2001, English translation 2017), which is where, out of all his works, Valkeapää connects Sámi values most strongly to those of other Indigenous peoples' values.

\section{HOLY PLACES}

strange rocks trees

hollows high up on the mountain

as long as we are open we will receive messages 
many messages

as long as we see we will learn

if birds if animals

behave strangely then they

come to us

to tell us

and some places some plants

rocks mountains the bedrock

they let us know

(Valkeapää 2017: 315)

The essential ability to listen in order to hear the message that is being expressed goes all the way back to the Sámi muitalus (a true story compared to a máinnas, which is a made-up story) about the time when the Creator placed the living and beating heart of a two-year-old reindeer cow at the center of the Earth, so that every time the Sámi felt their future and their existence threatened, they could just lay their ears to the ground and listen for the heartbeats from below. If the heart was still beating, that meant there would be a solution to the problems, and that there was still a future for the Sámi. The story shows us how far back the acknowledgement of the necessity of being able to listen to (to hear and to read) our environment goes.

An interesting linkage is between the trivializing of Indigenous perspectives and the trivializing of Elders' role as leaders, and that both of these trends are designed to disempower Indigenous people and keep the control in the hands of authorities who want to make the decisions over important matters without Indigenous input or approval. It is in this sense a bit disturbing to see the extent to which indigenous communities themselves seem to have begun to apply the same kind of dealing with their elderly people as what has been going on in the mainstream society for quite a while already. If the indigenous peoples themselves are prepared to forgo what I in this essay have called the Elders' approach - and which actually to a certain degree is analogous with Indigenous knowledge - who will then 
be left to defend the value of what we otherwise like to name the collective wisdom of a community? This is not only the case in indigenous communities, but all over the place. Still, since indigenous rhetoric emphasize the role of the Elders more than their neighboring majority communities do, one would expect indigenous leaders to be more aware of and occupied by the treatment of the Elders' role.

So, what does Elders' knowledge mean for today's society, other than the respect they deserve for the things they have achieved and brought about? Obviously very little, if we are to judge from the actual situation of Elders in contemporary, modernized Indigenous communities. Everyone - especially the politicians - speaks warmly about the importance of taking good care of Elders and listening to their wisdom, but generally that is just rhetoric, without any obvious implications. How can one learn anything from the Elders when stories more and more are looked upon as just stories? Current Indigenous societies are about to lose their ability to think metaphorically in order to learn the indirect way, which is one of the basic, implicit pedagogical values of sharing knowledge through stories.

The young people of today may well sit down for a while to listen to stories, but then it usually is in an organized manner, the storytelling taking place in a school or a public library or of course, when they are visiting their grandparents. Still, the context is more of a pastime activity than part of upbringing or a kind of apprenticeship, like it used to be. Traditionally a child would join an Elder in an activity where the aim would be to teach the young one the practice of, for instance, how to put up a trap or a snare, how to make a bowl or a knife, how to sew, or some other skill the adolescent would need to know. This teaching was conducted more or less unnoticed, because the child was so occupied listening to the story that learning the necessary skills almost came as a surplus, as an addition to listening ... guldalit. The story, then, would later connect with the skills learned, and thus the apprentice would have gained doubly; having learned important survival skills and a great story - which serves not only as an entertaining supplement to the knowledge, but, in fact, as an integrated, conceptual part of the learning process.

This is why children are raised with proverbs, sayings and stories, so that even if they don't understand the meaning there and then, it remains lodged in their consciousness, as unrealized knowledge, but with a potential for expanding their horizons and understanding when the need for just this knowledge is actualized later in life, through the experiences they 
have, which suddenly bring their thoughts back to what they remember of their parents' and other relatives' stories and experiences.

In this way, knowledge will never go out of date, because it is simply that portion of the traditional stories that are relevant for the situation one finds oneself in at the moment. From this it follows that the more of this type of experience one has, the wiser one will be as a person - based on generations' worth of collected knowledge and experience. It is obvious, then, that the Elders will have the largest store of this type of experience-based knowledge, so therefore they also earn the position of the community's knowledge-bearers.

\section{Five wolves, a horse, and a man}

This is my father-in-law's story. It was wintertime, and he was out in the forest with his horse, bringing home firewood he had cut down in the fall and left to be fetched when it was easier to transport home in a sled on snow, instead of having the horse pull a cart on bare ground. This was his final ride, so the tracks were good and solid already. The horse was pulling the sled with great ease, so both the animal and the driver were happy and satisfied with a good day's work. All of a sudden the horse got uneasy, kind of nervous. My father-in-law immediately understood what was going on. He could almost smell the fear in the air, and in just a few seconds 3 or 4 wolves appeared on the sled-track, right in front of them. They were followed by a few more wolves. The wolves stopped and observed the horse with the sled and the man atop the pile of trees on it. My father-in-law had learned that one should not try to shout at a wolf, nor look him into the eye. The wolf was expected to have a kind of magic power over people; if a person screamed at a wolf, the belief was that the wolf could "steal" that person's voice. Not eternally, but for a while, meaning that that person would not be able to utter a word, and definitely not be able to scare the wolf away by shouting. So, my father-in-law just sat on the pile of trees on the sled, looking at the wolves standing partly on the tracks and partly in the loose snow on both sides of the track. The horse was an old and wise animal, so he didn't panic, since his master stayed calm. The wolves and the man with his horse were fully aware that both sides were assessing the situation, the wolves obviously considering the pros and cons of a sudden attack, while the man was estimating the danger of 
making the horse move on, and thus hopefully making the wolves give way to the horse and sled. He took a chance and made a sound to the horse, which reacted instantly, and to their surprise the wolves gave way - they moved away from the tracks, and stood on both sides, just watching the sled pass by.

While my father-in-law was telling me this story some thirty or forty years later, one early morning over coffee in the kitchen of the home he had built for himself and his family, I could still sense the nervousness and tension he must have felt when the horse started to pull the sled past the wolf pack. "Did you turn around to make sure the wolves wouldn't attack you from behind when you were past the pack?" I asked. "No, I didn't," my father-in-law replied. "It would have proven to the wolves that I was nervous, which might have triggered them to attack. I also felt," he added, "that while we were watching each other, judging each other's strength, we made a gentlemen's agreement to let it go this time. I was sitting too high up on the pile of trees on the sled, and the horse looked too calm for the wolves to feel superior, in spite of their number."

The rest of the story is actually another story, about my father-in-law belonging to the generation of postwar entrepreneurial people who didn't allow themselves any rest or opportunity to sit down just in order to relax and enjoy life. Storytelling, I think, was in his view a waste of time, an unproductive activity that only elderly people had time to engage in. Even though my father-in-law actually was an elderly man at the time he shared the story with me, in his mind, I think, he still viewed himself as industrious and always occupied with some kind of project, so when he realized how much time he had spent on telling me the story, he was almost ashamed of himself, and immediately excused himself and ran off to fetch some meat from the freezer that we were going to have for dinner, mocking himself for acting like an old man wasting time with nonsense. He wouldn't listen at all to my compliments about his story being really intriguing, but I still think I could see a tiny smile on his face as a sign of recognition and satisfaction, which was actually confirmed at the after-dinner coffee, when he proclaimed to the whole household that he had entertained me with a wolf story for more than an hour in the morning. I can still remember the surprise and amazement on the faces of his wife, his son, and the youngest daughter of the house, because none of them knew him as a storyteller, 
but rather as an engaged tiller of the soil. I can also still remember the satisfaction I felt for being the one with whom he decided to share his story.

The indirect way implies patience. Sometimes it takes years to understand the full content of a story. For my own part, it took me so long to realize the full potential, grasp the whole context, of what my uncle was telling me when he taught me how to put up a snare for ptarmigan (arctic grouse) that he actually had died before his teachings dawned on me. I feel it is appropriate to conclude an essay like this with a(nother) story, because that has beenand still is - appreciated as the Indigenous Elders' way of transmitting knowledge.

I have told this story once before, in an essay that I was invited and inspired to write by my late Native American friend and colleague, Louis Owens, for the Weber study in 1999. I want to quote it as it is represented in the journal Weber: The Contemporary West. The story goes like this:

The making of a snare to catch the ptarmigan; with both entrance and fence, measuring out, bit by bit, the proper height for the trap, goapmir ja ceakko bealgi (literally, the hand and the thumb pointing upward), knowledgeable guidance given by an uncle who seemed to have an endless amount of time to teach you the task with care. For it had to be done correctly. Even if the snare was placed 150 meters from the house, where the ptarmigan never came, it had to be put together correctly, "because how could you ever put together a snare in the woods, when you perhaps are both tired and cold, if you don't learn how to do it correctly now." And the next day, on skis over the heath, off we went to set some real snares, where the ptarmigans stroll - yes, really stroll - since only two-legged creatures vázzet or vihket (walk or run), four-legged ones ruhttet (trot in a way only four-legged creatures can). That's how I learned about that, and how to capture ptarmigan, but it wasn't until thirty years later that I began to wonder why my uncle always had so much time to teach me all kinds of things. And why should I, this little skinny kid, learn to do everything so meticulously? Never was I allowed to be sloppy with anything, it had to be done properly, as if an adult had done it, even if it was done in miniature version. 
Not until later did I understand that the Sami upbringing of children was at that time more a communal matter than it is now, that my father's older brother had a great pedagogical responsibility for his nephew, and that language was such a large part of what the children had to learn. Therefore, the tale, not the actual adventure, but the fictional tale based on reality, was an important companion to the learning process. We always talked a lot as we walked, as we worked, while we were having coffee and dipping the lump of sugar in the coffee, sucking it and dipping it one last time before it melted in the mouth. We talked, and a whole world of experiences was implanted in me, without my being conscious of it until thirty years later, when my uncle had been dead for a long time and I no longer could ask him if he knew how pedagogical he was. And this double learning, hands-on experience combined with mastery of language which stemmed from work but also gave the child tools with which to fly, lifted daily chores to abstract heights, where the buzzard soars and is able to watch earthly labor from another angle. Did my uncle know that he was giving me wings, or did he just do what tradition dictated as his responsibility? How much was intentional, pedagogically structured teaching, how much was tradition's subtlety? What was important for my uncle was that I should learn to manage in this world. With regard to that, too, the Sami method of learning was important, because it made room for double heights; we learned the practical activity by learning to do the work, and we learned to master the task verbally by learning the concepts related to it. But we also learned the possibilities for abstraction, which language provided because of its multifacetedness, through the stories that accompanied work, and by listening to the adults' conversations about what we had learned, said and done. We often didn't recognize ourselves in all that they were saying, but it must have been funny, because they were laughing. We never felt they were laughing at us, but at their own renditions of our activities based on their teaching. We were left with not only a feeling, but a certainty that language is a fantastic tool with which one can create one's own reality (Gaski 1999).

\section{References:}

Allen, Chadwick 2012. Trans-Indigenous. Methodologies for Global Native Literary Studies. Minneapolis: University of Minnesota Press. 
Gaski, Harald 2017. Indigenous Aesthetics. Add Context to Context. Sámi Art and Aesthetics. Eds. Aamold, S, E. Haugdal \& U.A. Jørgensen. Aarhus: Aarhus University Press 2017: 179193.

Gaski, Harald 1999. "A Language to Catch Birds With." Weber: The Contemporary West 16 (2).https://www.weber.edu/weberjournal/Journal_Archives/Archive_C1/Vol_16_2/HGaskiEs s.html

Hart, Michael Anthony 2010. Indigenous Worldviews, Knowledge, and Research: The Development of an Indigenous Research Paradigm. Journal of Indigenous Voices in Social Work, Vol. 1, Issue 1.

Kappfjell, Lena \& H. Gaski 2017. Dåajmijes vuekie lea saemien vuekie. DIN:

Religionsvitenskapelig tidsskrift nr. 2, 2018: 12-19.

Keskitalo, Alf Isak 1974. Research as an inter-ethnic relation. Acta Borealia B. Humaniora. No. 13, Tromsø: Tromsø Museum.

Kovach, Margaret 2009. Indigenous methodologies. Characteristics, Conversations, and Contexts. Toronto: University of Toronto Press.

Kovach, Margaret 2005. Emerging from the Margins: Indigenous methodologies. L. Brown \& S. Strega (Eds.), Research as Resistance: Critical, Indigenous, anti-oppressive approaches. Toronto, Ontario, Canada: Canadian Scholars' Press.

Krupat, Arnold 2013. Nationalism, Transnationalism, Trans-Indigenism, Cosmopolitanism: Four Perspectives on Native American Literatures. Journal of Ethnic American Literature, Issue 3.

Krupat, Arnold 2002. Red Matters. Native American Studies. Philadelphia: University of Pennsylvania Press.

Krupat, Arnold 1992. Ethnocriticism. Ethnography, History, Literature. Berkeley: University of California Press.

Smith, Graham Hingangaroa 2003. Kaupapa Maori Theory: Theorizing Indigenous Transformation of Education \& Schooling. Kaupapa Maori Symposium, Auckland, NZ.

Smith, Linda 2012. Decolonizing Methodologies. 2nd edition. London: Zed Press.

Smith, L.T. 2000. Kaupapa Maori Research. In: M.Battiste (Ed.) Reclaiming indigenous voice and vision. Vancouver: UBC Press, pp. 225-247.

Thornton, Russel 1998. Studying Native America: Problems and Prospects. Madison: University of Wisconsin Press.

Valkeapää, Nils-Aslak 2017. The Earth, My Mother. Guovdageaidnu: DAT. (Sami original, Eanni, eannážan, 2001). 
Wheeler, Winona 2001. Thoughts on the Responsibilities for Indigenous/Native Studies. The Canadian Journal of Native Studies XXI, Vol. 1, pp. 97-104.

Wilson, Shawn 2008. Research is Ceremony. Indigenous Research Methods. Halifax \& Winnipeg: Fernwood Publishing.

Womack, Craig 1999. Red on Red: Native American Literary Separatism. Minneapolis: University of Minnesota Press. 